\title{
Rapid diagnosis of an outbreak of legionnaires' disease at Glasgow Royal Infirmary
}

\author{
JOHN H WINTER, A C MCCARTNEY, R J FALLON, A B M TELFER, J K DRURY, \\ I J REECE, M C TIMBURY
}

From the Departments of Respiratory Medicine, Microbiology, Anaesthetics, Peripheral Vascular Surgery, and Cardiothoracic Surgery, Glasgow Royal Infirmary, and the Department of Laboratory Medicine, Ruchill

Hospital, Glasgow

ABSTRACT In the last three months of 1985 there was an outbreak of legionnaires' disease at Glasgow Royal Infirmary affecting 15 patients and one surgeon; five patients died. Legionnaires? disease was first suspected when a second case of severe nosocomial pneumonia occurred in a higho dependency unit. The application of the direct fluorescent antibody test to specimens obtained at? bronchoscopy was responsible for the rapid diagnosis of legionnaires' disease, which led to thछ prescription of appropriate antibiotic treatment and the shutting down of the contaminated cooling tower, thereby containing the outbreak. It also led to a search for further cases. It is suggested that these diagnostic techniques should be included in the investigation of affected patients in an out $\frac{0}{\Sigma}$ break of pneumonia.

Legionnaires' disease is an important cause of outbreaks of nosocomial pneumonia, ${ }^{1}$ some outbreaks of which have been associated with a high mortality rate. $^{2}$ Legionella pneumophila serogroup (SG) 1 is responsible for most cases. Such outbreaks are usually related to contamination of water or cooling towers of ventilation systems by $L$ pneumophila; thus it is of great importance to establish whether an outbreak of pneumonia is caused by $L$ pneumophila, so that prompt measures can be taken to identify the source, eradicate the organism, and thereby halt the outbreak. Rapid diagnosis led to the early containment of a recent outbreak of legionnaires' disease at Glasgow Royal Infirmary, details of which are given elsewhere. $^{3}$

\section{Methods}

Glasgow Royal Infirmary is a teaching hospital with 918 beds. The infirmary has two buildings, one of traditional Victorian design and a new four floor building opened in 1983. Levels 3 and 4 contain respectively the peripheral vascular and cardiothoracic surgical units.

Address for correspondence: Dr J Winter, Respiratory Unit, King's Cross Hospital, Dundee DD3 8EA. (Reprints will not be available.)
DIAGNOSIS OF LEGIONNAIRES' DISEASE

Bronchial aspirates and sputum samples were exame ined by a direct fluorescent antibody test with monof clonal antibody to $L$ pneumophila SG1. These samples were also cultured on buffered charcoal yeast extract agar with and without added antibiotics and incus bated at $37^{\circ} \mathrm{C}$ in the presence of $5-10 \%$ carbon dioxide. Plates were examined daily for one week. Serum samples were assayed by the indirect fluorescent antis body test. ${ }^{3}$ A diagnosis of legionnaires' disease was made if one of the following criteria was met: (1) $\vec{G}$ pneumophila SG1 present in respiratory secretions (culture or direct fluorescent antibody test); (2) fourfold rise in antibody titre to $L$ pneumophila SGP; (3) a convalescent antibody titre to $L$ pneumophi SGl of $\geqslant 256$.

\section{Results}

The diagnosis of nosocomial legionnaires' disease w first contemplated on 1 November, when a secons case of severe postoperative pneumonia occurred $\mathrm{m}$ the high dependency area of the vascular surgery unif Serum and respiratory tract secretions were obtaine from both patients for Legionella serological tests and culture respectively. On 2 November three furthe patients with pneumonia were identified in the sane unit and one of the initial patients died. Sputum frogi 
Table 1 Diagnosis of 16 cases of legionnaires' disease, 1985

\begin{tabular}{|c|c|c|c|c|c|c|c|c|c|}
\hline \multirow{3}{*}{$\begin{array}{l}\text { Patient } \\
\text { No }\end{array}$} & \multicolumn{3}{|c|}{$\begin{array}{l}\text { Direct fluorescent antibody test for } \\
\text { L pneumophila serogroup } 1\end{array}$} & \multicolumn{2}{|c|}{$\begin{array}{l}\text { Culture for } L \text { pneumophila } \\
\text { serogroup } 1\end{array}$} & \multicolumn{4}{|c|}{$\begin{array}{l}\text { Serum antibody titre to L pneumophila } \\
\text { serogroup } 1\end{array}$} \\
\hline & \multirow[b]{2}{*}{ Specimen } & \multirow[b]{2}{*}{ Date } & \multirow[b]{2}{*}{ Result } & \multirow[b]{2}{*}{ Result } & \multirow{2}{*}{$\begin{array}{l}\text { Days taken } \\
\text { for culture }\end{array}$} & \multicolumn{2}{|c|}{$\begin{array}{l}\text { First sample } \\
\text { obtained }\end{array}$} & \multicolumn{2}{|c|}{$\begin{array}{l}\text { Earliest sample } \\
\text { giving diagnostic }\end{array}$} \\
\hline & & & & & & Date & Titre & Date & Titre \\
\hline 1 & $\begin{array}{l}\text { Tracheal aspirate } \\
\text { Bronchial lavage }\end{array}$ & $\begin{array}{l}1 \text { Nov } \\
4 \text { Nov }\end{array}$ & $\begin{array}{l}\text { Negative } \\
\text { Negative }\end{array}$ & $\begin{array}{l}\text { Positive } \\
\text { Positive }\end{array}$ & $\begin{array}{l}5 \\
4\end{array}$ & 31 Oct & $<16$ & \multicolumn{2}{|c|}{$\begin{array}{l}\text { No diagnostic titre } \\
\text { obtained }\end{array}$} \\
\hline 2 & $\begin{array}{l}\text { Sputum } \\
\text { Post mortem lung }\end{array}$ & $1 \mathrm{Nov}$ & $\begin{array}{l}\text { Positive } \\
\text { Positive }\end{array}$ & $\begin{array}{l}\text { Positive } \\
\text { Positive }\end{array}$ & $\begin{array}{l}3 \\
5\end{array}$ & 31 Oct & $<16$ & \multicolumn{2}{|c|}{$\begin{array}{l}\text { No diagnostic titre } \\
\text { obtained }\end{array}$} \\
\hline 3 & Sputum & 2 Nov & Positive & Positive & 5 & 4 Nov & $<16$ & $11 \mathrm{Nov}$ & 64 \\
\hline 4 & Bronchial lavage & 2 Nov & Positive & Positive & 3 & 4 Nov & $<16$ & 11 Nov & 512 \\
\hline 5 & Bronchial lavage & 2 Nov & Positive & Positive & 3 & 4 Nov & $<16$ & $8 \mathrm{Nov}$ & 128 \\
\hline 6 & Bronchial lavage & 3 Nov & Negative* & Negative* & - & $7 \mathrm{Nov}$ & 256 & $7 \mathrm{Nov}$ & 256 \\
\hline 7 & $\begin{array}{l}\text { Bronchial lavage } \\
\text { Sputum }(28 / 10 / 85)\end{array}$ & $\begin{array}{l}3 \text { Nov } \\
4 \text { Nov }\end{array}$ & $\begin{array}{l}\text { Positive } \\
\text { NT }\end{array}$ & $\begin{array}{l}\text { Negative } \\
\text { Positive }\end{array}$ & $\overline{2}$ & 1 Nov & $256 \dagger$ & 1 Nov & $256 \dagger$ \\
\hline 8 & Bronchial lavage & 3 Nov & Positive & Negative & - & 4 Nov & $<16$ & 19 Nov & 32 \\
\hline 9 & Tracheal aspirate & 4 Nov & Positive & Negative & - & 4 Nov & $<16$ & \multicolumn{2}{|c|}{$\begin{array}{l}\text { No diagnostic titre } \\
\text { obtained }\end{array}$} \\
\hline 10 & Bronchial lavage & $5 \mathrm{Nov}$ & Negative & Positive & 3 & 5 Nov & $<16$ & \multicolumn{2}{|c|}{$\begin{array}{l}\text { No diagnostic titre } \\
\text { obtained }\end{array}$} \\
\hline 11 & - & - & - & - & - & 15 Nov & 256 & $15 \mathrm{Nov}$ & 256 \\
\hline 12 & - & - & - & - & - & 4 Nov & 256 & $4 \mathrm{Nov}$ & 256 \\
\hline 13 & - & - & - & - & - & 4 Nov & $<16$ & 12 Nov & 256 \\
\hline 14 & - & - & - & - & - & 2 Dec & 2048 & 2 Dec & 2048 \\
\hline 15 & - & - & - & 一 & - & 29 Nov & 256 & 29 Nov & 256 \\
\hline 16 & - & - & - & - & - & 4 Nov & $<16$ & $13 \mathrm{Nov}$ & 64. \\
\hline
\end{tabular}

*Unsatisfactory specimen.

+Result of test with heat killed antigen. ${ }^{4}$

findirect fluorescent antibody test with formalin-killed agar grown antigen.

NT-not tested.

patients 2 and 3 (table 1) was thought possibly to be positive for $L$ pneumophila on examination by the direct fluorescent antibody test; but in patients 4 and 5 , who underwent fibreoptic bronchoscopy, $L$ pneumophila SG1 was identified without doubt by the direct fluorescent antibody test in the bronchial lavage samples. This established the existence of an outbreak of legionnaires' disease at the Royal Infirmary and led to action to define and contain the outbreak.

A search of the new building for patients with pneumonia was made and by 4 November a total of seven cases of legionnaires' disease had been diagnosed by the direct fluorescent antibody test from bronchial aspirates (five cases) and sputum (two cases). These patients had all been nursed in the high dependency units on the third and fourth floors of the new building; these areas had been closed on 2 and 3 November respectively and the use of the new building was restricted to emergency admissions only. Over the next four days a further four cases were diagnosed, two by culture and two by serology. In addition, a member of the medical staff who had been resident in one of the high dependency units was shown on serological investigation to have had legionnaires' disease. Some weeks later a diagnosis of legionnaires' disease was made by serology in four patients who had been discharged from the affected areas of the Royal Infirmary; three had had mild respiratory symptoms but one had been symptom free.

The direct fluorescent antibody test confirmed the clinical diagnosis, within a few hours, in seven patients. Cultural confirmation was obtained within two to four days in seven patients. Serological study of blood samples from the first 10 patients at time of diagnosis was, in general, unhelpful; results of microbiological investigations are summarised in table 1 .

Details of the individual cases are given in table 2 . With the exception of the staff member (case 11) and one medical patient (case 10), all patients had recently undergone major surgery. The four patients who were discovered after discharge from hospital to have been infected are shown in the lower part of the table (cases 13-16).

The antibiotics used in this outbreak and their daily dosages were erythromycin $4 \mathrm{~g}$, ciprofloxacin $800 \mathrm{mg}$, and rifampicin $1.2 \mathrm{~g}$; patient 2 received only erythro- 
Table 2 Details of 16 patients with legionnaires' disease*

\begin{tabular}{|c|c|c|c|c|}
\hline $\begin{array}{l}\text { Patient } \\
\text { No }\end{array}$ & Age & Sex & Operation & Outcome \\
\hline 1 & 71 & $\mathbf{M}$ & Aorta biprofundoplasty & Died \\
\hline 2 & 57 & $\mathbf{M}$ & $\begin{array}{l}\text { Patch angioplasty to aortic } \\
\text { bifurcation graft }\end{array}$ & Died \\
\hline 3 & 63 & $\mathbf{M}$ & $\begin{array}{l}\text { Extension to aortic bifurcation } \\
\text { graft }\end{array}$ & Died \\
\hline 4 & 59 & $\mathbf{M}$ & Aortic bifurcation graft & Survived \\
\hline 5 & 70 & $\mathbf{F}$ & Aortic bifurcation graft & Survived \\
\hline 6 & 60 & $\mathbf{M}$ & Coronary bypass graft & Survived \\
\hline 7 & 57 & $\mathbf{M}$ & Coronary bypass graft & Died \\
\hline 8 & 66 & $\mathbf{F}$ & Aortic bifurcation graft & Survived \\
\hline 9 & 67 & $\mathbf{M}$ & $\begin{array}{l}\text { Resection of abdominal aortic } \\
\text { aneurysm }\end{array}$ & Died \\
\hline 10 & 58 & $\mathbf{M}$ & $\begin{array}{l}\text { None; polyarthritis: having } \\
\text { prednisolone } 50 \text { mg daily }\end{array}$ & Survived \\
\hline 11 & 27 & $\mathbf{M}$ & $\begin{array}{l}\text { None; staff member sleeping } \\
\text { in affected area }\end{array}$ & Survived \\
\hline 12 & 64 & $\mathbf{M}$ & Aortic bifurcation graft & Survived \\
\hline 13 & 65 & $\mathbf{F}$ & Aortic bifurcation graft & Survived \\
\hline 14 & 60 & $\mathbf{F}$ & Mitral valve replacement & Survịved \\
\hline 15 & 59 & $\mathbf{F}$ & $\begin{array}{l}\text { Mitral valve replacement; } \\
\text { coronary bypass graft }\end{array}$ & Survived \\
\hline 16 & 56 & $\mathbf{M}$ & Coronary bypass graft & Survived \\
\hline
\end{tabular}

${ }^{*}$ Cases 13-16 were diagnosed serologically after discharge.

mycin, patient 10 received erythromycin with ciprofloxacin, and seven patients were treated with a combination of all three drugs. Patients 6, 11, and 12 received a course of erythromycin even though they were already recovering from their pneumonia.

Five patients died. Patient 2 had fulminating disease and died 48 hours after the first clinical suspicion of pneumonia; patients 1 and 7 had required intermittent positive pressure ventilation for six and four days respectively before the diagnosis was made and both had renal failure. Patients 3 and 9 received erythromycin, ciprofloxacin, and rifampicin within 24 hours of becoming dependent on a ventilator; patient 3 died from the adult respiratory distress syndrome rather than from the infection per se, and patient 9 made a good recovery from pneumonia but suffered a fatal pulmonary embolism.

A search of hospital records of patients who had died of pneumonia or respiratory failure of unknown aetiology some weeks before the outbreak, revealed a case in September 1985. This patient developed fever, bilateral pulmonary infiltrates, and respiratory failure after coronary artery surgery; an initial diagnosis of the adult respiratory distress syndrome was made at necropsy. The diagnosis of legionnaires' disease was established late in November by the demonstration of L. pneumophila SG1 by direct fluorescent antibody test in postmortem lung tissue. Review of the notes suggest that the infection was acquired in hospital.

\section{Discussion}

This was, in many ways, a typical nosocomial out- break 'of legionnaires' disease. It affected predominantly surgical patients who after operation had beento housed in high dependency areas of the peripheral-흐 vascular and cardiothoracic units. Some cases weres recognised only as a result of a deliberate search. Of ${ }^{\mathbb{Q}}$ the 12 patients who developed the disease while ino hospital in the Royal Infirmary, all had pneumonia and four showed the multisystem disease reported by. others. ${ }^{5}$ Most were men, probably reflecting the pre- $\vec{\omega}$ ponderance of men admitted to the peripheral vascu- $⿴$ lar and cardiothoracic surgical units. Two patients $\vec{x}$ were immunocompromised; patient 3 had undergone splenectomy in the past and patient 1 was receiving prednisolone for polyarteritis. The remaining patientsi may have been vulnerable to infection by the respira-ब tory route because they had recently had anaesthetics은 for major surgery. In addition, all of these patients received prophylactic antistaphylococcal antibiotics? at operation and immediately afterwards; possibly을 such treatment affected the resident bacterial flora and thereby facilitated invasion by $L$ pneumophila. $\vec{\bullet}$ Members of staff rarely develop clinical disease in nosocomial outbreaks ${ }^{1}$ but here a healthy young surgeon who had slept in a small room in the cardio-o thoracic high dependency area did become ill. Two of 5 his colleagues who also occupied this room during? their nights on duty were unaffected and did not develop antibody to $L$ pneumophila.

Although the number of patients was too small toō allow statistical analysis, there was a clinical impression that early treatment with erythromycin and ciprofloxacin with or without rifampicin was an: effective treatment in this disease. Despite intensive treatment, however, five of the nine patients who were severely ill died.

The most notable feature of this outbreak of legionnaires' disease was the rapidity with which ai firm diagnosis was made. As has previously been illustrated in a group of immunocompromised patients, 0 the application of the direct fluorescent antibody test to bronchial lavage specimens obtained at bron- $\frac{D}{0}$ choscopy resulted in a confident diagnosis within a few hours. ${ }^{6}$ As a result the contaminated hospitalo cooling tower was immediately shut down, althoughn microbiological proof of contamination was notN obtained until some days later. ${ }^{3}$ Legionnaires' disease ${ }_{\sigma}^{\omega}$ is most commonly diagnosed by serological techniques, but positive serolegical results may not be $\subseteq$ obtained until some weeks after the onset of disease. $\stackrel{7}{-}$ If we had relied on serological techniques for diagnosis, the outbreak might not have been recognised for some time, and if the number of patients had been $\vec{\Phi}$ small it might have been missed altogether, like the $\frac{O}{\mathbb{P}}$ case diagnosed retrospectively on examination of postmortem tissue.

Postoperative respiratory complications, including 
pneumonia, are common in patients recovering from major surgery and it is exceedingly difficult, if not impossible, to make a clinical diagnosis of legionnaires' disease. We would suggest that the methods outlined above should be used in the investigation of nosocomial pneumonia so that Legionella pneumophila, if it is the cause, can be identified, appropriate antibiotic treatment can be administered, and immediate measures can be taken to identify the source and eradicate the organism.

We wish to acknowledge the generous gift of monoclonal antibody by Inveresk Research Ltd to Dr R J Fallon. We are grateful to Bayer UK for supplying the ciprofloxacin used in these patients. The cooperation of administrative, engineering, medical, nursing, and paramedical staff during the outbreak was greatly appreciated.

\section{References}

1 Fallon RJ. Nosocomial infections with Legionella pneumophila. J Hosp Infect 1980;1:299-305.

2 Band JD, Fraser DW. New bacterial infections. Legionellosis. In: Reeves DS, Geddes AM, eds. Rec $A d v$ Infect. Vol 2. Edinburgh: Churchill Livingstone, 1982: 101-17.

3 Timbury MC, Donaldson JR, McCartney AC, et al. Outbreak of legionnaires' disease in. Glasgow Royal Infirmary: microbiological aspects. J Hyg Camb 1986;97:393-403.

4 Fallon RJ. Laboratory diagnosis of legionnaires' disease. Association of Clinical Pathologists Broadsheet 1981; No 99.

5 Tsai BD, Finn DR, Plikaytis BD, et al. Legionnaires' disease: clinical features of the epidemic in Philadelphia. Ann Intern Med 1979;90:509-17.

6 Kohorst WR, Schonfeld SA, Macklin JE, Whitcomb ME. Rapid diagnosis of legionnaires' disease by bronchoalveolar lavage. Chest 1983;84:186-90.

7 Macfarlane JT, Finch RG, Ward MK, Macrae AD. Hospital study of adult community-acquired pneumonia. Lancet 1982;ii:255-8. 